\title{
COST OPTIMIZATION AND RISK MINIMIZATION DURING TEAMWORK ORGANIZATION
}

\author{
Marek KRYNKE, Krzysztof MIELCZAREK \\ Czestochowa University of Technology \\ Olga KIRILIUK \\ Omsk State Transport University Omsk
}

\begin{abstract}
:
In the paper the problem of personnel allocation under threat was presented. The possibilities of undertaking optimization measures in the process of workers' health and safety and expenses incurred were emphasized. A mathematical model for this issue has been formulated. An algorithm solving the problem of staff allocation was presented. The evaluation criterion for this assignment was the minimization of worker safety risks. Simultaneous optimization of expenses incurred in the implementation of production tasks was taken into account. The productivity of the staff and all existing jobs with the skills of the employees also was considered. This problem was solved using GNU Octave. The example presented in the paper shows that in case of the most unfavorable allocation of tasks to employees, it will lead to a significant reduction in profits and may increase the risk of undesirable situations. The proposed analysis is the starting point for determining the risk in case of multi-position work.
\end{abstract}

Key words: work organization, multi-station work, risk management, linear programming

\section{INTRODUCTION}

Uncertainty and associated with this risks are everywhere and all the time. The starting point for managing with this phenomena is perceiving them in order to deal with them in turbulent reality. The result of uncertainty existence is the risk. It is often limited to threats defined as the probability of a negative event occurring. In order to survive on market, organizations should be proactive in the face of uncertainty, and should seek opportunities when risking [26]. Uncertainty is a dynamic category reflecting the state of knowledge. The accompanying risk category is the uncertainty function. Uncertainty and risk is a function of the quantity and quality of information. It is at the disposal of the decision maker and the variability of macro and micro-environment conditions, internal and external factors at the disposal of the decision-maker and the variability of macro and micro-environment conditions, internal and external factors [15].

In recent years, the topic of risk management has become more important because appropriate project management techniques are now seen as a way to achieve the desired change in the company. In addition, projects are characterized by increasing complexity, the use of various skills and technologies, and the resulting dependencies lead to a higher degree of uncertainty in the outcome of a given project $[23,27]$.
All ventures involve some kind of risk. This may be due to the nature of the work (e.g. if there are many new elements), the type of available resources, the contracts in force or the political factors affecting the project. All risk should usually not be eliminated, this can block innovation and suppress creativity [5].

However, it is possible to manage projects in a way that recognizes the existence of risk and prepares methods if this risk actually occurs.

work organization is an activity aimed at obtaining the highest work efficiency by creating better working conditions. Increased work efficiency affects the financial results achieved by the enterprise. Work organization can concern own work or teamwork. The division of labor is the basis of the work organization, which is necessary due to the high complexity of tasks [24, 25].

There can be various production planning problems. In planning, it is necessary to determine the most favourable organizational solutions of cooperating means of work [10], allocate production tasks, determine the needs and availability of resources $[4,6]$, assess the costs of work, analyse the risks [12] etc. However, the basic planning issue is the appointment of a team to perform a specific scope of work in the determined or sought optimal risk. 
Selected issues from this set will be the subject of considerations and proposals of planning techniques in this work.

\section{RISK MANAGEMENT}

Risk management has become a determinant and an integral element of organizational culture. This means translating into strategic, tactical and operational goals as well as a strict definition of people's responsibility in terms of individuals, functions and territories. In Industry 4.0 concept, risk management is a proactive activity aimed at better resource management $[7,20]$.

Risk management includes both an evaluation undertaking as well as planning and control activities aimed at minimizing risk or maintaining it at an acceptable level. Safety management can be reduced to the issue of risk management, because risk is a quantitative expression of the functioning of systems in an environment where are current sources of threats to the safety of systems $[8,9,28]$. Risk management requires (Fig. 1):

- Identification of the mechanisms to keep risk under control and ensure that it is taken into account,

- measures identifying potential risk in the undertaking,

- assessment of the likelihood of potential risk materializing,

- assessment of the likely effects of the risk,

- formulating actions to avoid the risk,

- development of the risk reduction measures if risk avoidance measures fail,

- determining the urgency of the risk and taking appropriate countermeasures.

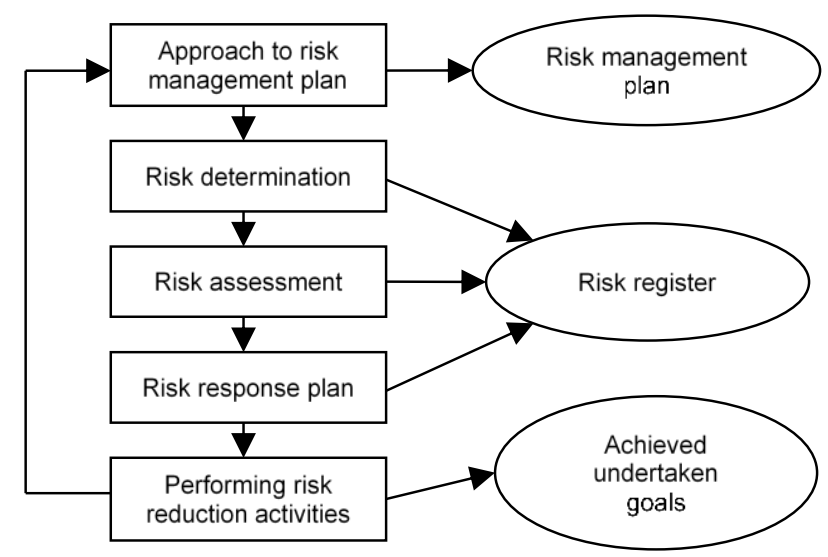

Fig. 1 Risk management process

When defining a threat, it is taken into account that each threat has two characteristics:

- uncertainty - a hazard may or may not occur,

- loss - if a hazard occurs, it will cause some loss or other undesirable effects.

Due to the different risks identified, it is necessary to estimate their impact and likelihood of occurrence. Then it is possible to focus on those types of risks which have the highest probability of occurrence and on those which, if they occur, will cause the highest damage to the project [11].
In the paper an example to illustrate the risk assessment problem was used. Let's consider the risk of poor contractor performance. More precisely, this risk can be broken down into three elements:

- staff do not work at the pace set in preparing estimates,

- the personnel do not comply with the programming standards of the system developer,

- inexperienced team managers have difficulty in managing personnel.

The significance of these effects will depend on the volume of the performed work. If we use many external contractors, then these effects can be serious. If these contractors constitute only a small part of the executive team, then the impact will be smaller [21]. Sometimes it is necessary to estimate the impact, for example by calculating the probability of occurrence and assessing whether the impact is large, moderate or small. A risk map can be used for this purpose [16, 27].

The risk map shows the impact of each type of risk on one axis and their probability on the other (Table 1) [29]. The types of risk shown in the lower left corner are those that have the greatest impact and probability. Hence, presumably, they will require the most attention.

Table 1

Risk level expressed in the form of impact $S$ and their probability $P$

\begin{tabular}{ccccccc}
\hline $\begin{array}{c}\text { Impact (S) } \\
\text { /Probability (P) }\end{array}$ & $\mathbf{1}$ & $\mathbf{2}$ & $\mathbf{3}$ & $\mathbf{4}$ & $\mathbf{5}$ \\
\hline 1 & 1 & 2 & 3 & 4 & 5 \\
\hline 2 & 2 & 4 & 6 & 8 & 10 \\
\hline 3 & 3 & 6 & 9 & 12 & 15 \\
\hline 5 & 4 & 8 & 12 & 16 & 20 \\
\hline
\end{tabular}

The risk scoring makes it possible to order the risks according to their severity or the criteria of the risk scoring matrix. For the different values of the product of probability and impact, appropriate reactions shall be determined. Risks with high probability and high impact (high) require urgent attention from the organization. Risks with low probability and high impact and low impact and high probability of occurrence (averages, which are in the middle of the risk assessment matrix) shall be discussed and monitored. In some cases the organization may take further action. Risks with low impact and low probability (low) represent the lowest risk to the organization [18, 27].

The optimization of the production process is performed in the following areas of the company's level of action: management, human, environment, tool, machine and production [3]. The starting point for this improvement can be the Ishikawa diagram, which is used to identify specific causes of problems in different areas [1, 2, 22]. 


\section{RESEARCH PROBLEM}

A certain company dealing in the production of steel constructions (balustrades, exit gates, fence spans) must plan its monthly activity in order to get the highest profit possible. The company has at its disposal the following orders, which will require the following works:

- Z1 - cutting steel sections,

- Z2 - welding steel elements (balustrades, entrance gates),

- Z3 - preparation of products for varnishing, grinding joints, cleaning, etc.,

- Z4- lacquering of products,

- Z5 - montage of balcony balustrades,

- Z6 - montage of entrance gates and fence spans.

To describe a given situation with a mathematical model, a way to characterize tasks using numbers should be found. Important parameters are the employee's salary and the time needed to perform a specific task (Table 2).

Table 2

Number of work units required for a given order and remuneration per unit of work for a given order

$\begin{array}{lllllll}\text { Task type } & \text { Z1 } & \text { Z2 } & \text { Z3 } & \text { Z4 } & \text { Z5 } & \text { Z6 }\end{array}$

Required number of work units
$[\mathrm{h}]$ 50400150100150100

Gross income for man-hour

[PLN]

Five employees work in the company. The working time and remuneration of employees can be clearly described numerically. It was assumed that employees E1 and E2 are employed full-time (140h), employees E3, E4 part-time (70h), overtime if necessary while employee E5 a contracted employee. The most difficult issue is the assessment of work efficiency. The solution to this problem is to determine the effectiveness coefficients of a given employee working on a given task. Table 3 presents the preference matrix and employee remuneration.

Table 3 Employee preference matrix for particular tasks

\begin{tabular}{lccccc}
\hline \multicolumn{1}{c}{ Employee } & E1 & E2 & E3 & E4 & E5 \\
\hline Working time $[\mathrm{h}]$ & 140 & 140 & $>70$ & $>70$ & $>0$ \\
Earning per hour $[\mathrm{PLN}]$ & 20 & 25 & 30 & 30 & 35 \\
$\mathrm{Z1}$ & 1 & 0.5 & 0.7 & 2 & 1.5 \\
$\mathrm{Z} 2$ & 1.9 & 1.8 & 0.6 & 2 & 1.1 \\
$\mathrm{Z3}$ & 0.8 & 2 & 1.6 & 1.9 & 1.3 \\
$\mathrm{Z4}$ & 1.5 & 0.8 & 0.8 & 1 & 0.9 \\
$\mathrm{Z} 5$ & 0.8 & 1.9 & 0.6 & 1.1 & 1.2 \\
$\mathrm{Z6}$ & 0.9 & 2 & 1.7 & 2 & 1.3 \\
\hline
\end{tabular}

In Table 4 the risk of employees performing individual production tasks is assigned. The impact of each type of risk and its probability of occurrence were considered.
Table 4

Risk level expressed in the form of impact $S$ and their probability $P$

\begin{tabular}{|c|c|c|c|c|c|c|c|c|c|c|}
\hline \multirow{3}{*}{$\begin{array}{l}\text { Employee } \\
\text { Type of risk }\end{array}$} & \multirow{2}{*}{\multicolumn{2}{|c|}{ E1 }} & & & \multirow{2}{*}{\multicolumn{2}{|c|}{ E3 }} & \multirow{2}{*}{\multicolumn{2}{|c|}{ E4 }} & & \\
\hline & & & \multicolumn{2}{|c|}{ E2 } & & & & & \multicolumn{2}{|c|}{ E5 } \\
\hline & $\begin{array}{l}\bar{\Xi} \\
\tilde{U} \\
\tilde{0} \\
\stackrel{0}{E} \\
\underline{E}\end{array}$ & $\begin{array}{l}a \\
\frac{a}{2} \\
\frac{ \pm}{0} \\
\frac{0}{\pi} \\
\frac{0}{0} \\
\frac{0}{0}\end{array}$ & $\begin{array}{l}\bar{\Xi} \\
\underline{\tilde{E}} \\
\text { o } \\
\underline{\underline{E}}\end{array}$ & 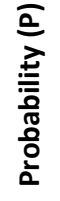 & 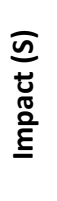 & 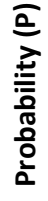 & 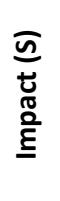 & 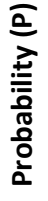 & 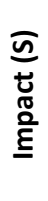 & $\begin{array}{l}\text { a } \\
\frac{2}{2} \\
\frac{ \pm}{0} \\
\frac{0}{\pi} \\
\frac{0}{0} \\
\frac{0}{0}\end{array}$ \\
\hline Z1 & 1 & 3 & 4 & 5 & 3 & 5 & 1 & 3 & 4 & 3 \\
\hline Z2 & 5 & 1 & 2 & 1 & 1 & 3 & 4 & 2 & 4 & 5 \\
\hline Z3 & 2 & 4 & 3 & 3 & 2 & 2 & 3 & 4 & 5 & 2 \\
\hline Z4 & 4 & 4 & 2 & 4 & 1 & 2 & 1 & 2 & 3 & 1 \\
\hline Z5 & 2 & 1 & 4 & 5 & 4 & 2 & 2 & 5 & 1 & 1 \\
\hline Z6 & 3 & 5 & 2 & 4 & 4 & 2 & 2 & 3 & 2 & 2 \\
\hline
\end{tabular}

The mathematical model of the classical problem of employee allocation can be presented as a problem of minimizing the cost function $[13,14]$. Two optimization cases were included in this study. The first taking into account the minimization of costs and risks (function $F_{c r}$ ) and the second case concerning the minimization of costs only (function $F_{c}$ ):

$$
\begin{gathered}
F_{c r}=\sum_{i=1}^{5} \sum_{j=1}^{6}\left(h_{j i} \cdot S_{j i} \cdot P_{j i} \cdot w_{i}\right) \rightarrow \min \\
F_{c}=\sum_{i=1}^{5} \sum_{j=1}^{6}\left(h_{j i} \cdot w_{i}\right) \rightarrow \min
\end{gathered}
$$

where:

$h_{j i}$ - number of possible employee's working hours $i$ for task $j$,

$S_{j i}$ - employee risk impact coefficient $i$ performing task $j$,

$P_{j i}$-employee risk probability coefficient $i$ performing task j,

$w_{i}$ - salary for an employee $i$.

It is a function that should be minimized. At the same time, the available standard hours of work:

$$
\begin{gathered}
h_{11}+h_{21}+h_{31}+h_{41}+h_{51}+h_{61}=140 \\
h_{11}+h_{21}+h_{31}+h_{41}+h_{51}+h_{61}=140 \\
h_{13}+h_{23}+h_{33}+h_{43}+h_{53}+h_{63}>70 \\
h_{14}+h_{24}+h_{34}+h_{44}+h_{54}+h_{64}>70 \\
h_{15}+h_{25}+h_{35}+h_{45}+h_{55}+h_{65}>0 \\
h_{13}+h_{24}+h_{34}+h_{43}+h_{54}+h_{63}<200 \\
h_{14}+h_{24}+h_{34}+h_{44}+h_{54}+h_{64}<200 \\
h_{15}+h_{25}+h_{35}+h_{45}+h_{55}+h_{65}<200
\end{gathered}
$$

and requirement concerning production order - limitations of work units:

$$
\begin{aligned}
& h_{11} a_{11}+h_{12 a_{12}}+h_{13} a_{13}+h_{14 a_{14}}+h_{15} a_{15}=50 \\
& h_{21} a_{21}+h_{22} a_{22}+h_{23} a_{23}+h_{24} a_{24}+h_{25} a_{25}=400 \\
& h_{31} a_{31}+h_{32} a_{32}+h_{33} a_{33}+h_{34} a_{34}+h_{35} a_{35}=150 \\
& h_{41} a_{41}+h_{42} a_{42}+h_{43} a_{43}+h_{44} a_{44}+h_{45} a_{45}=100 \\
& h_{51} a_{51}+h_{52} a_{52}+h_{53} a_{53}+h_{54} a_{54}+h_{55} a_{55}=150 \\
& h_{61} a_{61}+h_{62} a_{62}+h_{63} a_{63}+h_{64} a_{64}+h_{65} a_{65}=100
\end{aligned}
$$
where:

$a_{i j}$ - elements of the matrix containing constraint coefficients.

A defined task is possible to be solved in the environment Octave. Octave is a free programme for numerical calculations (mathematical and engineering calculations). This language is intuitive and friendly (for a mathematician) [17]. With basic functionality in Octave there are operations on matrices and number of numerical methods solving linear and non-linear problems. Octave is software 
featuring a high-level programming language, primarily intended for numerical computations. Octave helps in solving linear and nonlinear problems numerically, and it is used for performing other numerical experiments with the use of a language that is mostly compatible with MATLAB.

The issue of assigning employees to particular tasks was solved using the GLPK command. The GNU Linear Programming Kit (GLPK) is a software package intended for solving large-scale linear programming (LP), mixed integer programming (MIP), and other related problems [19].

GLPK uses the revised simplex method and the primaldual interior point method for non-integer problems and the branch-and-bound algorithm together with Gomory's mixed integer cuts for (mixed) integer problems.

\section{ANALYSIS OF THE RESULTS}

After the calculations, the optimal values of working hours of individual employees was obtained. In Fig. 2 optimal assigning project tasks to employees was described.

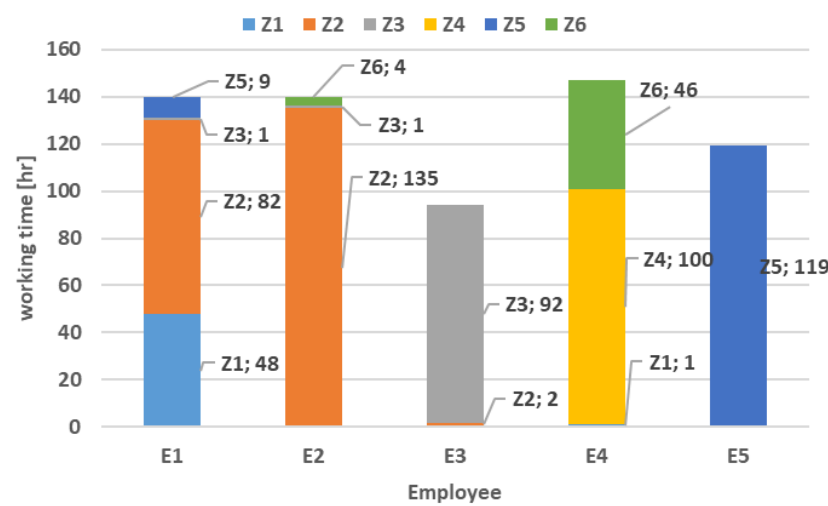

Fig. 2 Optimal assigning tasks to individual employees

In Figure 2 it was shown that employees E1 and E2 use the entire working time, while employees $E 3$ and $E 4$, who are employed part-time, have to work in overtime.

The figure compares two extreme cases of allocating tasks to employees. The first - the most desirable, taking into account the minimization of risk and costs, and the second - the least favourable, for the maximization of costs and risk.

Figure 3 presents risk maps for the four extreme cases of optimizing the analysed problem.

Figures $3 a$ and $3 b$ relate to the objective function (2) which does not include risk analysis. In turn, in Figures $3 \mathrm{c}$ and $3 \mathrm{~d}$ a situation where cost optimization also includes risk minimization was shown.

The presented maps clearly show that it is important to consider risk in optimizing production costs. a)

$=0-1=1-2=2-3$
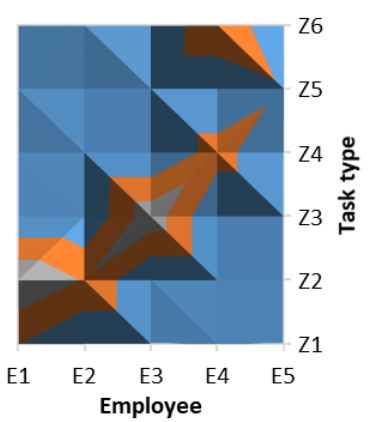

c)
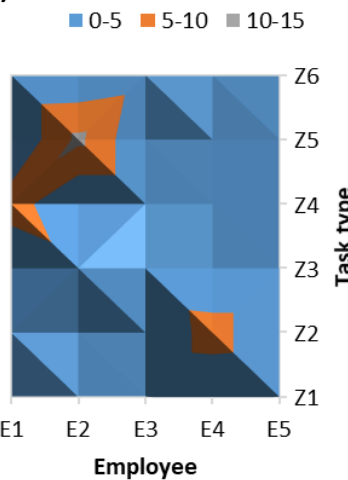

b)
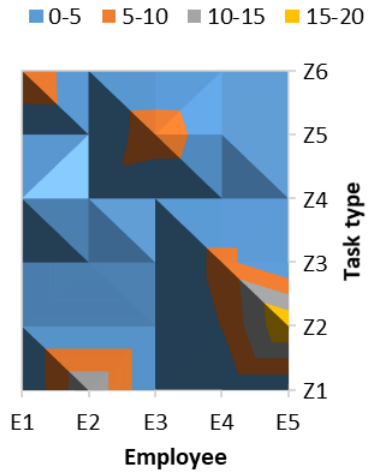

d)
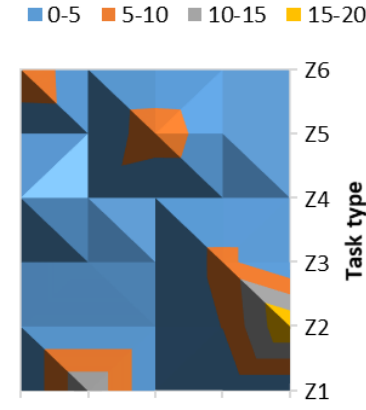

E1 E2 E3 E4 E5 Employee
Fig. 3 Risk map for the case: a) maximizing costs, b) minimizing costs, c) maximizing costs and risk, d) minimizing costs and risk

Figure 4 presents a graph in which the resultant risk numbers for various optimization criteria are compared. In addition, the maximum risk that will occur when allocating a given employee to a given workplace is shown. Of course, the best results are obtained taking into account the risk analysis in the allocation of tasks to individual employees.

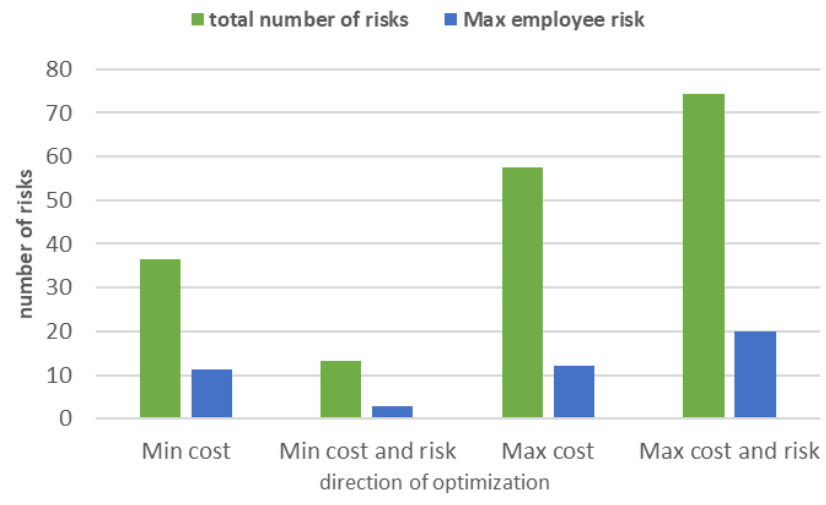

Fig. 4 The number of risks for various optimization criteria

In Figure 5 the profit generated by the individual employees was presented. An interesting situation occurred in the case of employee E5. As a highly qualified employee, it has relatively high pay. So much that the execution of such tasks entrusted to him bring loss.

In Figure 6 a graph that compares the total cost of the realization of the order program for four extreme cases was presented. 


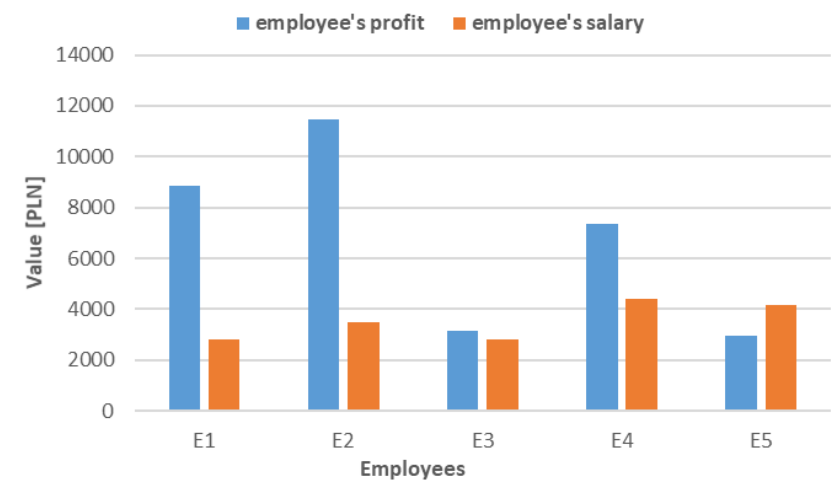

Fig. 5 Profit generated by the individual employees

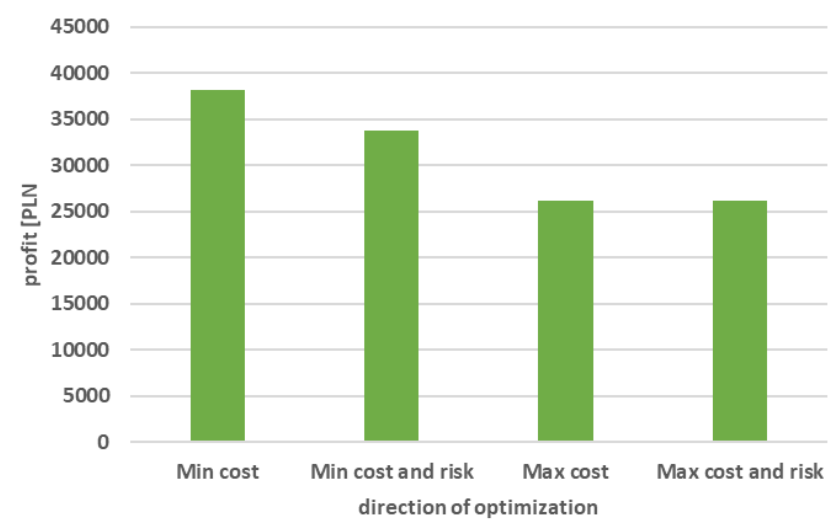

Fig. 6 Total profit of the realization of the production program for various optimization criteria

The first situation concerns the optimal solution, when profits are subjected to the maximization by minimizing costs without considering the risk. For comparison, the second one shows a situation when profits were also maximized but additionally minimized risk. The next two cases show extremely undesirable situations where costs and risks are greatest. It should be noted that in the first case a profit is obtained by $13 \%$ higher than in situation 2 , however, with almost 3 times higher risk. Therefore, the best assignment of tasks to employees is considered to be the solution obtained while minimizing costs and risk.

\section{CONCLUSION}

Risk cannot be completely avoided, but it can be managed when is recognized and its impact avoided or mitigated. There are many areas where risk for the project may arise, starting with business, commercial and contractual risk to technical risk. The basic sequence of actions in risk management is its identification, assessment and formulation and implementation of risk reduction measures.

Problems related to the assignment of employees to perform specific works are often trivialized. Most often, contractors want to accomplish tasks quickly, without thinking about the global effects of such behaviour. The adduced example shows that in the case of the most unfavourable allocation of tasks to employees, it will lead to a significant reduction in profits and may increase the risk of undesirable situations. It is also possible that there may be a situation in which the optimal assignment of tasks causes that some employees bring a loss (situation of the E5 employee in the adducted analyses). However, in global terms it is still beneficial for the implementation of specific orders.

The above mathematical model and the method of its solution is applicable in many engineering problems, e.g. the problem of optimal use of resources, implementation of the cheapest order, etc.

The presented example can be analogously extended to a larger number of employees and tasks as well as months.

\section{REFERENCES}

[1] S. Borkowski, M. Ingaldi, M. Jagusiak-Kocik. „Quality analysis and technological portfolio in production of the metal screws." METAL 2014 - 23 $3^{\text {rd }}$ International Conference on Metallurgy and Materials, Conference Proceedings, 2014, pp. 1716-1722.

[2] S. Borkowski, J. Rosak-Szyrocka, D. Klimecka-Tatar, M. Jagusiak-Kocik, P. Sygut. „Determination of the technology place in the metal company on the basis of the Toyota's management principles." METAL 2013 - 22nd International Conference on Metallurgy and Materials, Conference Proceedings, 2013, pp. 1691-1696.

[3] D. Danalakshmi, R. Gopi, A. Hariharasudan, I. Otola, Y. Bilan. „Reactive power optimization and price management in microgrid enabled with blockchain." Energies, vol. 13, no. 23, pp. 6179, 2020.

[4] M. Drljača. "Reversible Supply Chain in function of competitiveness." Production Engineering Archives, vol. 22, pp. 30-35, 2019.

[5] J. Grabara. „Sustainable development - Never fulfilled dream." Quality - Access to Success, vol. 20, pp. 565-570, 2019.

[6] A. Grzelczak. „Norma czasu a zarządzanie produkcją w aspekcie pracy wielostanowiskowej." Innowacje w Zarządzaniu i Inżynierii Produkcji, Knosala R. (red.), Oficyna Wydawnicza Polskiego Towarzystwa Zarzqdzania Produkcja, 2018, pp. 432-440.

[7] M. Ingaldi, R. Ulewicz. "Problems with the implementation of industry 4.0 in enterprises from the SME sector." Sustainability (Switzerland), vol. 12, no. 1, pp. 217, 2020.

[8] K. Kapustka, G. Ziegmann, D. Klimecka-Tatar, M. Ostrega. "Identification of health risks from harmful chemical agents - review concerning bisphenol A in workplace" Production Engineering Archives, vol. 26, no. 2, 2020, doi: 10.30657/pea.2020.26.10

[9] K. Kapustka, G. Ziegmann, D. Klimecka-Tatar, S. Nakonczy. „Process Management and Technological Challenges in the Aspect of Permanent Magnets Recovery - the Second Life of Neodymium Magnets." Manufacturing Technology, vol. 20, no. 5, pp. 617-624, 2020.

[10] M. Klimek, P. Łebkowski. „Algorytm dla problemu losowego przydziału personelu." Logistyka, vol. 2, pp. 299-306, 2011.

[11] K. Knop. "Statistical analysis of responses concerning the importance of human and production or services issues in various companies." Production Engineering Archives, vol. 7, pp. 40-44, 2015.

[12] D. Kozioł-Kaczorek, Ł. Pietrych. „Grafy a teoria stabilnych alokacji.” Ekonometria Econometrics, vol. 3, no. 53, pp. 102-114, 2016.

[13] M. Krynke. "Risk Management in the Process of Personnel Allocation to Jobs." System Safety: Human - Technical Facility - Environment, (red.) Ulewicz R., Nikolic Ruzica R., De Gruyter, Warszawa 2020, pp. 82-90. 
[14] M. Krynke, K. Mielczarek. "Applications of linear programming to optimize the cost-benefit criterion in production processes." MATEC Web of Conferences, vol. 183, pp. 6, 2018.

[15] K. Lisiecka. "Risk Management and Quality of Enterprise Management." Zarzqdzanie i Finanse, vol. 10, no. 3, pp. 553-569, 2012.

[16] K. Mielczarek, K. Knop. "Assessment of production processes functioning in the case of air bag production." $M A$ TEC Web of Conferences, pp. 183, 2018.

[17] S. Nagar. "Introduction to Octave: For Engineers and Scientists." Apress, NewYork, 2018.

[18] M. Niciejewska, O. Kiriliuk. "Occupational health and safety management in small size enterprises, with particular emphasis on hazards identification." Production Engineering Archives, vol. 26, no. 4, pp. 195-201, 2020.

[19] A. Piechna. „Zadanie programowania liniowego w środowisku GNU Octave." Projektowanie i Konstrukcje Inżynierskie, vol. 55, 58-62, 2012.

[20] J. Pietraszek, N. Radek, A.V. Goroshko. "Challenges for the DOE methodology related to the introduction of Industry 4.0." Production Engineering Archives, vol. 26, no. 4, 190194, 2020.

[21] J. Rosak-Szyrocka, A.A. Abbase. „Quality management and safety of food in HACCP system aspect." Production Engineering Archives, vol. 26, no. 2, pp. 50-53, 2020.

[22] D. Siwiec, A. Pacana. Identifying the source of the problem by using implemented the FAHP method in the selected quality management techniques." Production Engineering Archives, vol. 26, no. 1, pp. 5-10, 2020.

\author{
Marek Krynke \\ ORCID ID: 0000-0003-4417-1955 \\ Czestochowa University of Technology \\ ul. Dąbrowskiego 69, 42-201 Częstochowa, Poland \\ e-mail: marek.krynke@wz.pcz.pl
}

\section{Krzysztof Mielczarek}

ORCID ID: 0000-0003-3701-0192

Czestochowa University of Technology

ul. Dąbrowskiego 69, 42-201 Częstochowa, Poland

e-mail: krzysztof.mielczarek@wz.pcz.pl

\section{Olga Kiriliuk}

ORCID ID: 0000-0001-7892-6987

Omsk State Transport University

Omsk, Russian Federation

e-mail: olgaomgau@yandex.ru
[23] E. Staniszewska, D. Klimecka-Tatar, M. Obrecht. „Eco-design processes in the automotive industry." Production Engineering Archives, vol. 26, no. 4, pp. 131-137, 2020.

[24] M. Starostka-Patyk, P. Tomski, M. Zawada. „Diversity Management as a Part of Corporate Social Responsibility Policy." Procedia Computer Science, vol. 65, pp. 1038-1045, 2015.

[25] P. Tomski, E. Wysłocka. "The entrepreneurial perception of the small enterprise Environment." Global Journal of Environmental Science and Management, vol. 5 (Special Issue), pp. 180-187, 2019.

[26] R., Ulewicz, M. Ulewicz. "Problems in the Implementation of the Lean Concept in the Construction Industries." Lecture Notes in Civil Engineering, vol. 47, pp. 495-500, 2020.

[27] D. Wróblewski. „Zarządzanie ryzykiem - przegląd wybranych metodyk." Wydawnictwo CNBOP-PIB2015, doi: $10.17381 / 2015.1$

[28] J. Żywiołek. "Monitoring of information security system elements in the metallurgical enterprises." MATEC Web of Conferences, vol. 183, 01007, 2018.

[29] J. Żywiołek. "Value stream mapping in the process of knowledge exchange while maintaining data security in a manufacturing company." Conference Quality Production Improvement-CQPI, vol. 2, no. 1, pp. 11-18, 2020. 